\title{
Posture and body image in individuals with major depressive disorder: a controlled study
}

\section{Postura e imagem corporal em indivíduos com depressão: um estudo controle}

\author{
Janette Zamudio Canales, ${ }^{1}$ Táki Athanássios Cordás, ${ }^{2}$ Juliana Teixeira Fiquer, $^{3}$ André Furtado Cavalcante, ${ }^{1}$ \\ Ricardo Alberto Moreno ${ }^{1}$ \\ ${ }^{1}$ Grupo de Doenças Afetivas (GRUDA), Institute and Department of Psychiatry, Universidade de São Paulo Medical School (FMUSP), São \\ Paulo, SP, Brazil \\ ${ }^{2}$ Eating Disorders Program (AMBULIM), Institute and Department of Psychiatry, Universidade de São Paulo Medical School (FMUSP), São \\ Paulo, SP, Brazil \\ ${ }^{3}$ Department of Experimental Psychology, Institute of Psychology, Universidade de São Paulo (USP), São Paulo, SP, Brazil
}

\begin{abstract}
Abtract
Objective: In this study, we aimed to quantify posture and body image in patients with major depressive disorder during episodes and after drug treatment, comparing the results with those obtained for healthy volunteers. Method: Over a 10-week period, we evaluated 34 individuals with depression and 37 healthy volunteers. Posture was assessed based on digital photos of the subjects; CorelDRAW software guidelines and body landmarks were employed. Body image was evaluated using the Body Shape Questionnaire. Results: During depressive episodes (in comparison with the post-treatment period), patients showed increased head flexion ( $\mathrm{p}<0.001)$, increased thoracic kyphosis $(\mathrm{p}<0.001)$, a trend toward left pelvic retroversion $(\mathrm{p}=0.012)$ and abduction of the left scapula $(\mathrm{p}=0.046)$. During remission, patient posture was similar to that of the controls. At week 1 (during the episode), there were significant differences between the patients and the controls in terms of head flexion ( $\mathrm{p}<0.001)$ and thoracic kyphosis $(\mathrm{p}<0.001)$; at weeks 8-10 (after treatment), such differences were seen only for shoulder position. The mean score on the Body Shape Questionnaire was 90.03 during the depressive episode, compared with 75.82 during remission $(\mathrm{p}=0.012)$ and 62.57 for the controls. Conclusion: During episodes of depression, individuals with major depressive disorder experience changes in posture and mild dissatisfaction with body image. The findings demonstrate that the negative impact of depression includes emotional and physical factors.
\end{abstract}

\section{Resumo}

Objetivo: O objetivo deste estudo foi avaliar quantitativamente a postura e a imagem corporal em pacientes com transtorno depressivo maior, durante o episódio depressivo e após tratamento medicamentoso, e comparar com voluntários sadios. Método: Durante o periodo de dez semanas, foram avaliados 34 indivíduos com depressão e 37 voluntários sadios. A postura foi avaliada através de fotos digitais e do software CorelDRAW. A imagem corporal foi avaliada através do Body Shape Questionnaire. Resultados: No episódio depressivo (em comparação ao periodo pós tratamento), os pacientes apresentaram aumento da flexão da cabeça $(p<0,001)$, aumento da cifose $(p<0,001)$, retroversão pélvica esquerda $(p=0,012)$ e abdução da escápula esquerda $(p=0,046)$. Na remissão, a postura foi similar ao grupo controle. Na comparação entre controles e transtorno depressivo maior, houve diferença para postura da cabeça $(p<0,001)$ e cifose torácica $(p<0,001)$. Na remissão houve diferença para a postura do ombro. A média dos escores do Body Shape Questionnaire foram 90,03 no episódio e 75,82 na remissão ( $p=0,012)$. O grupo controle apresentou escore 62,57. Conclusão: Houve diferença da postura e insatisfação da imagem corporal durante o episódio em individuos com transtorno depressivo maior. Os achados destacam que o impacto negativo da depressão abrange tanto fatores emocionais quanto fisicos.

Descritores: Postura; Depressão; Imagem corporal; Avaliação; Transtorno depressivo maior

Descriptors: Posture; Depression; Body image; Evaluation; Depressive disorder, major

\section{Introduction}

Depression is one of the most common psychiatric disorders in adults and is characterized by depressed mood, changes in appetite, disturbed sleep, reduced energy, tiredness, fatigue, anxiety and a lack of motivation. ${ }^{1}$ Clinical observation suggests that the appearance of patients with depression is distinct and recognizable, characterized by sad facial expression, furrowed
Submitted: September 17, 2009

Accepted: January 18, 2010

\section{Correspondence}

Janette Zamudio Canales

Rua Ovídio Pires de Campos 785, 3o. andar, Ala Norte - Cerqueira César 05403-010 São Paulo, SP, Brasil

Phone/fax: (+55 11) 3069-6648

Email: jane_canales@terra.com.br 
brow, curved shoulders and a lack of spontaneous body movements. ${ }^{2}$

Posture is defined as the position and relative arrangement of the body parts. The ideal alignment in the vertical posture allows the body to maintain its balance with a minimum expense of energy. ${ }^{3}$ By analogy, bad (or abnormal) posture means the defective relation among the multiple parts of the body. Postural problems typically generate higher tension over the supporting structures which constitute the musculoskeletal system. Posture is influenced by a number of conditioning factors: mechanical and emotional aspects; heredity and race; flexibility; muscle strength; vision; and habits. ${ }^{4-7}$ In addition, feelings of excitation, confidence and satisfaction manifest as an alert attitude and erect posture, whereas depression typically manifests as a slouching posture. ${ }^{8}$

Although no standard approach to assessing posture has been defined, the use of photos has been supported by many studies. ${ }^{9-11}$ Photogrammetry, defined as the interpretation of obtained values from a photographic image, is a quantitative technique that allows the angles and distances between bone references, joints, planes and axes to be measured, reliably assessing posture and identifying misalignment. ${ }^{?}$

Self-awareness of posture is linked to the concept of body image. Posture and body image are closely related. Body image determines differences and plasticity of the postural organization. Due to constant changes in position, tactile and visual perceptions continuously force the remodeling of the posture. ${ }^{12}$ Body image is defined as the mental perception of the size, contour and shape of our bodies, as well as our feelings related to those characteristics and to the parts that constitute our body. Therefore, body image has two major components: a perception component, related to the self-estimated body size, and an attitude component, related to affect and cognition. ${ }^{13}$ Body image disturbances are seen in neurological and psychiatric disorders.

Most reports on the posture of depressed patients have been observational. In addition, most studies on this topic have assessed eating disorders or have evaluated only depressive symptoms. ${ }^{14}$ To our knowledge, there have been no studies quantitatively evaluating posture and body image in patients with major depressive disorder (MDD). Therefore, this study aims to evaluate the posture and body image in individuals with MDD during episodes and remission, and we compare the results with those obtained for a control group consisting of healthy volunteers.

\section{Method}

\section{Design}

This was a 10 -week, observational case-control study. Our sample consisted of 34 individuals with MDD, from 20 to 50 years of age, receiving care at the Mood Disorders Unit of the Psychiatry Institute of the Universidade de São Paulo Hospital das Clínicas, a public hospital located in the city of São Paulo, Brazil. The diagnosis of MDD was made in accordance with the Diagnostic and Statistical Manual of Mental Disorders, Fourth Edition (DSM-IV), text revision criteria. A score $\geq 18$ on the 17-item Hamilton Rating Scale for Depression (HAM-D-17) was considered indicative of an episode of depression (week 1), whereas a HAM-D-17 score $\leq 14$ was considered indicative of partial or total remission (weeks 8-10).

A control group $(\mathrm{n}=37)$ was composed of age- and gendermatched healthy individuals, identified from a previous study. ${ }^{15}$ None of the controls had any family or personal history of psychiatric disorder as evaluated by the 20-item Self-Reporting Questionnaire, ${ }^{15}$ as well as by DSM-IV. ${ }^{15}$ To rule out clinically relevant nonpsychiatric disorders, we applied a questionnaire regarding family history, as well as conducting laboratory tests, electrocardiograms and physical examinations. The exclusion criteria were as follows: presenting with a neuromuscular or musculoskeletal disorder; and exercising regularly (more than twice a week or more than three hours per week).

The project was approved by the local ethics committee, and the legal representatives of the subjects gave written informed consent.

\section{Procedures}

To conduct the postural assessments, we used photos of patients in the orthostatic position (sagittal and frontal planes), as previously described by Penha et al. ${ }^{16}$ Height and weight were measured before the images were taken, and the body mass index (BMI) was calculated. A room was reserved for posture evaluation and the patients were asked to stand on a wood base $(40 \times 40 \mathrm{~cm})$, which was positioned in front of a grid $(2 \times 1 \mathrm{~m}$; grid size, $10 \times 10 \mathrm{~cm})$.

A digital camera (Cybershot ${ }^{\circledR}$ DSC, 7.2 Megapixels; Sony Corporation, Tokyo, Japan) was rotated and locked in the vertical position $\left(90^{\circ}\right.$ from horizontal) in order to capture an image of the entire body. The camera was positioned at a standardized distance of $2.70 \mathrm{~m}$ from the grid and at a height of $1 \mathrm{~m}$. The upper part of the wood base coincided with the lowest grid line. The camera was aligned parallel with the floor through the use of the built-in bubble level. ${ }^{16}$

For each subject, the following bone reference points were marked with adhesive dots: lateral malleoli; head of the fibula; greater trochanter of the femur; anterior and posterior superior iliac spine; cervical spine (at C7); thoracic spine (at T3, T6, T9 and T12); lumbar spine (at L3 and L5); sacral spinous processes; and inferior scapular angle. ${ }^{5}$ Some of these reference points were also marked with small balls $(15 \mathrm{~cm}$ in diameter): anterior and posterior superior iliac spine; thoracic spine (at T3, T6, T9 and T12), lumbar spine (at L3 and L5); cervical spine (at C7); and acromion. ${ }^{5}$

Photos were imported into the CorelDRAW program, version 12 (Corel, Ottawa, Canada) and were enlarged in order to identify the reference points. Sagittal plane photos were used in order to assess head position, shoulder position, thoracic kyphosis, lumbar lordosis, pelvic inclination and knee position. Posterior plane photos were used in order to assess scapula and ankle position.

The Body Shape Questionnaire (BSQ) was used in order to evaluate subject body image. The BSQ consists of a Likert-type scale, including 34 questions related to concerns regarding body 
shape and weight, as well as affective, cognitive and behavioral aspects, over the past 4 weeks. Rankings are assigned by ordering the scores obtained by sum of points and categories: $\leq 80=$ no dissatisfaction; 81-110 = mild dissatisfaction; 111-139= moderate dissatisfaction; and $\geq 140=$ strong dissatisfaction. ${ }^{14}$

\section{Data analysis}

The angles between bone reference points were quantified in degrees and calculated using the CorelDraw guidelines. Data collection and measurements were performed by the same researcher. Measurements were taken twice (right and left sides) in the frontal, posterior and sagittal planes. ${ }^{16}$

Head position - In the sagittal plane, a horizontal line was drawn at C7 and a diagonal line was drawn from the point where that horizontal line met the spine to the external auditory meatus. We measured the angle between those two lines (Figure 1).

Thoracic kyphosis - In the sagittal plane, the angle between the point of greatest cervical concavity and that of greatest lumbar concavity was measured, the vertex being the highest point of thoracic convexity (Figure 1).

Lumbar lordosis - In the sagittal plane, the angle between the highest points of convexity on the thoracic curve and the gluteus region was measured, the vertex being the point of greatest lumbar concavity (Figure 1).

Pelvic inclination - In the sagittal plane, a horizontal line was drawn at the level of the anterior superior iliac spine, which is the vertex of the angle formed between that horizontal line and a second line ending at the posterior superior iliac spine (Figure 1).

Knee position - In the sagittal plane, the angle between the lateral malleoli, the head of the fibula and the greater trochanter of the femur was measured in order to identify hyperextension or semi-flexion (Figure 1).

Scapula position - In the posterior plane, the distance below the corresponding apophysis angle was measured in centimeters, in order to estimate abduction or adduction of the scapula.

Shoulder position - In the sagittal plane, the distance from the acromion to the $\mathrm{C} 7$ spinous process was measured in centimeters, in order to identify shoulder protraction (Figure 1).

Ankle position - In the posterior plane, the angle between a vertical line running through the Achilles tendon and the vertical line of the leg to the average midpoint of the calcaneus was measured.

\section{Statistics}

Data were analyzed using descriptive statistics and summary tables. The statistical analysis was performed using the following: Pearson's chi-square test to compare proportions between groups (e.g., gender); the $t$-test to compare age; the exact chi-square test for race; and the Mann-Whitney test for BMI. For quantitative variables, the Kolmogorov-Smirnov test was employed in order to determine the goodness of fit for normality; the paired $t$-test was performed for variables with normally distributed data within a group; and the Wilcoxon test for paired samples was used for

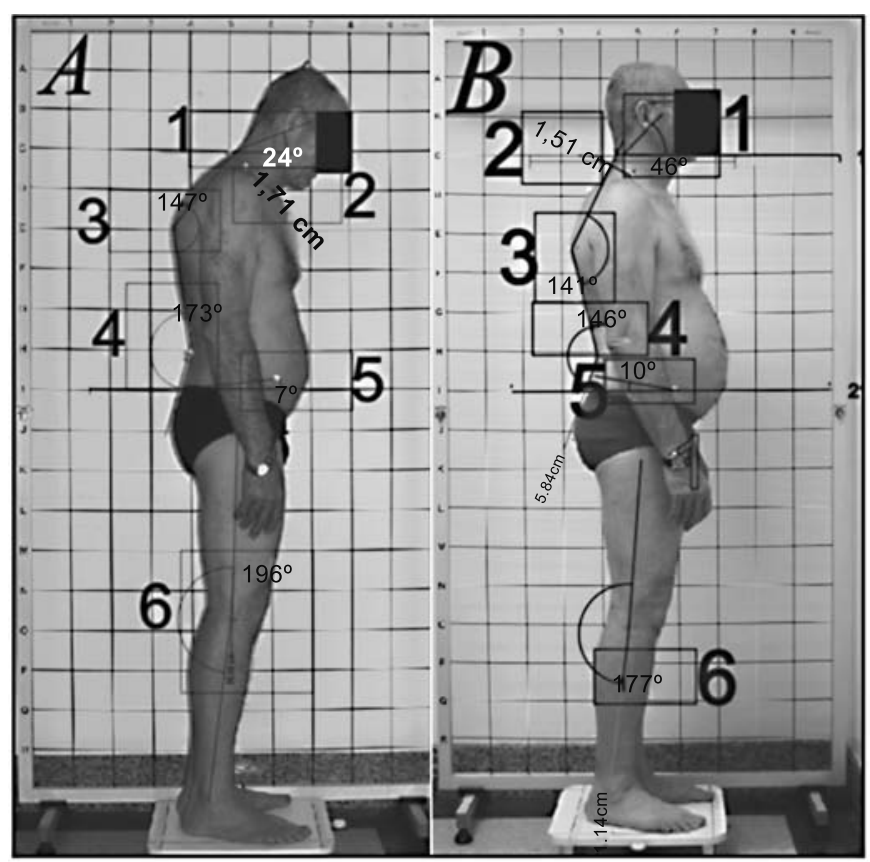

Figure 1 - Postural variables in an individual with MDD during an episode (A) and during remission (B). 1. Head position ( ${ }^{\circ}$ ); 2. Shoulder level $(\mathrm{cm}) ; 3$. Thoracic kyphosis $\left({ }^{\circ}\right)$; 4. Lumbar lordosis $\left({ }^{\circ}\right)$; 5. Pelvic inclination $\left({ }^{\circ}\right)$; 6. Knee position $\left({ }^{\circ}\right)$.

variables with non-normally distributed data. In the comparison between groups for postural variables, ANOVA was performed for normally distributed data and the Mann-Whitney test was used for non-normally distributed data. The Statistical Package for the Social Sciences, version 14.0 (SPSS Inc., Chicago, IL, USA) was used for statistical calculations.

\section{Results}

Our sample consisted of 34 individuals with MDD and 37 healthy controls. Females predominated in both groups $(76.5 \%$ and $78.4 \%$ ). The mean age was $37.62 \pm 8.20$ years in those with MDD and $34.78 \pm 6.21$ years in the control group. At weeks 8-10, mean BMI was $24.85 \pm 5.18 \mathrm{~kg} / \mathrm{m}^{2}$ in the MDD group, compared with $23.90 \pm 2.76 \mathrm{~kg} / \mathrm{m}^{2}$ in the control group. In terms of age, gender and BMI, the differences between the two groups were not significant $(\mathrm{p}=0.10, \mathrm{p}=0.848$ and $\mathrm{p}=0.23$, respectively).

At enrollment, $55.9 \%$ of the individuals with MDD were experiencing a severe recurrent episode, $11.8 \%$ were experiencing a moderate recurrent episode; $17.6 \%$ were experiencing a moderate first episode and $14.79 \%$ were experiencing a severe first episode. The mean HAM-D-17 score for the group was $26.65 \pm 4.24$ at week 1 and $6.91 \pm 3.80$ at weeks $8-10$.

Comparing week 1 with weeks 8-10 in terms of the postural variables in the MDD group, we observed significant differences for left side pelvic position $(\mathrm{p}=0.012)$, left scapular position $(\mathrm{p}=$ 0.046 ), right thoracic kyphosis ( $<<0.001)$, left thoracic kyphosis $(\mathrm{p}<0.001)$ and sagittal head position $(\mathrm{p}<0.001)$, as can be seen in Table 1 and Figure 1.

Table 1 shows that there were significant differences between the MDD group at week 1 and the control group in terms of 
Table 1 - Comparison of postural variables in individuals with MDD and controls

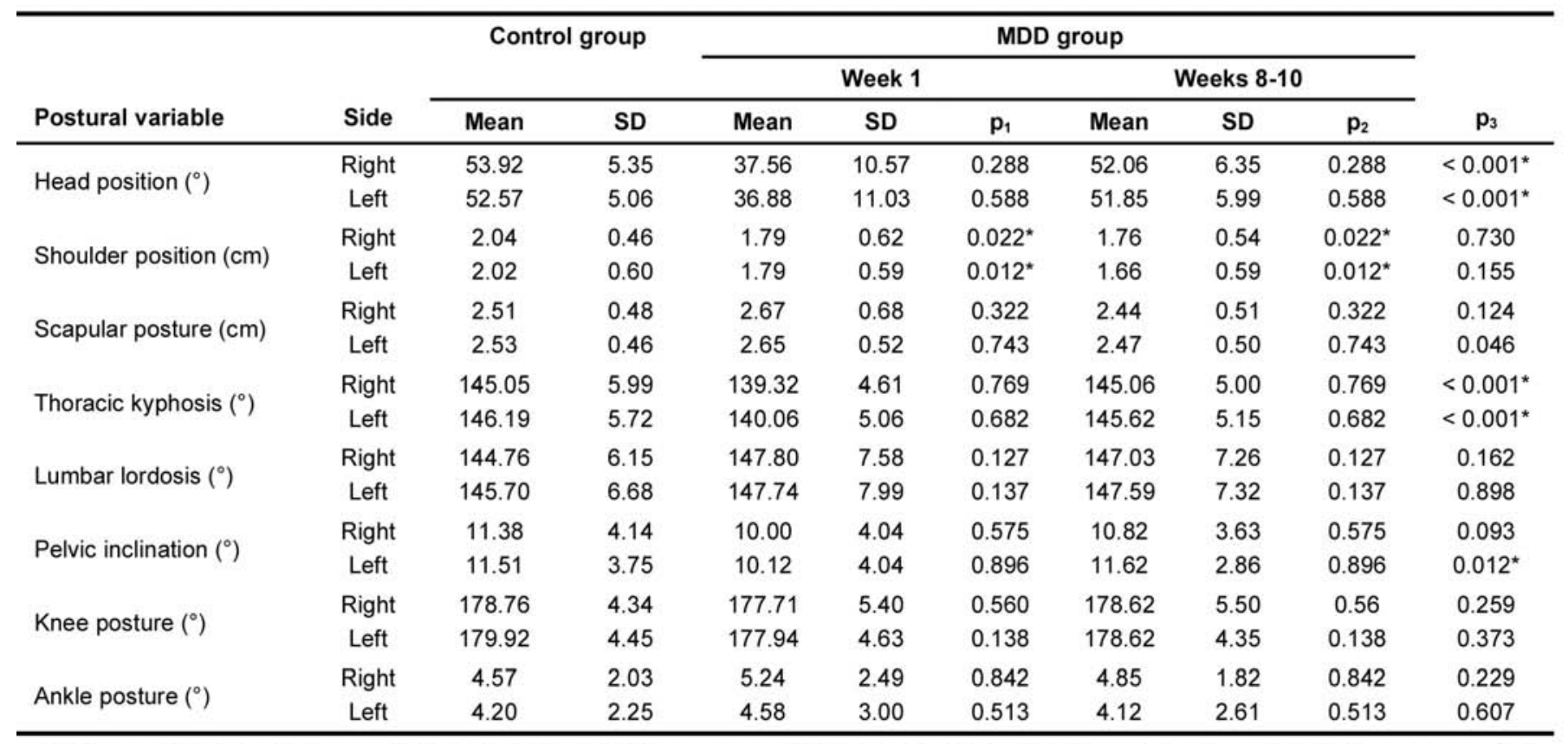

$M D D=$ major depressive disorder; $S D=$ standard deviation; $p_{1}=$ comparison between $M D D$ group at week 1 and control group; $p_{2}=$ comparison between MDD group at weeks 8-10 and control group; $p_{3}=$ comparison between week 1 and weeks 8-10 in the MDD group.

right sagittal head position $(\mathrm{p}<0.001)$, left sagittal head position $(\mathrm{p}<0.001)$, right thoracic kyphosis $(\mathrm{p}<0.001)$ and left thoracic kyphosis $(\mathrm{p}<0.001)$, whereas, at weeks $8-10$, such differences were seen only for position of the right and left shoulders $(\mathrm{p}=$ 0.022 and $\mathrm{p}=0.012$, respectively).

As can be seen in Table 2, the mean BSQ score in the MDD group was $90.03 \pm 38.46$ at week 1 and $75.82 \pm 35.30$ at weeks $8-10(\mathrm{p}=0.012)$. In the control group, the mean BSQ score was $62.57 \pm 23.04$. In terms of the BSQ score, there were no significant differences between the MDD group at weeks 8-10 and the control group ( $\mathrm{p}=0.127)$.

\section{Discussion}

\section{Postural variables}

Although there have been studies evaluating posture in various pathologies, few have done so in individuals with MDD, making it difficult to contextualize our results.

We found that, during episodes, patients with MDD showed marked anterior head carriage, tend to look at the floor, and that this was attenuated during remission.

The posterior cervical, trapezius and paraspinal muscles counterbalance the weight of the head, and anterior head carriage can therefore cause tenderness in the neck region. ${ }^{17}$ Using the Penha et al. methodology, ${ }^{16}$ Miranda $^{18}$ found the mean head position in a group of 37 healthy women to be $52.0 \pm 6.5^{\circ}$. Using the same methodology, Ferreira found the mean head position to be $47.06 \pm 4.77^{\circ}$ for a group composed of both genders. ${ }^{19}$ These values are similar to those obtained for our control group.

Patients presenting depressive episodes showed a marked increase in kyphosis, which was also reduced during remission. Kyphosis affects the muscles, reducing the flexibility of anterior thorax (intercostal) muscles, upper limb muscles originating from the thorax (minor and major pectoralis, latissimus dorsi and anterior serratus muscles) and cervical spine muscles (levator scapulae and trapezius muscles). ${ }^{17}$ In the study conducted by Miranda, ${ }^{18}$ the mean kyphosis angle was found to be $143.4 \pm$ $7.1^{\circ}$, similar to that found for our control group.

Table 2 - Body Shape Questionnaire and body mass index in individuals with MDD and controls

\begin{tabular}{|c|c|c|c|c|c|}
\hline \multirow[b]{3}{*}{ Parameter } & \multicolumn{2}{|c|}{ MDD group } & & \multicolumn{2}{|c|}{ Control group } \\
\hline & Week 1 & Weeks 8-10 & & & \\
\hline & mean (SD) & mean (SD) & $\mathbf{p}^{\star}$ & mean $(\mathrm{SD})$ & $\mathbf{p}^{\star \star}$ \\
\hline$B S Q$ & $90.03(38.46)$ & $75.82(35.30)$ & $0.012^{\star}$ & $62.57(23.04)$ & 0.127 \\
\hline BMI & $25.00(4.81)$ & $24.85(5.18)$ & 0.99 & $23.90(2.76)$ & 0.519 \\
\hline
\end{tabular}

MDD: major depressive disorder; SD: standard deviation; BMI: body mass index; BSQ: Body Shape Questionnaire.

*Comparison of mean scores between week 1 and weeks 8-10 in the MDD group (t-test)

${ }^{*}$ Comparison of mean scores between the MDD group at weeks 8-10 and the control group (t-test) 
In the present study, depressive patients tended to present with pelvic retroversion, which decreased during remission. The pelvis is the key to correct posture of the dorsal region, and the mean pelvic inclination in normal subjects is $11 \pm 44^{\circ} \cdot{ }^{17}$ Miranda found the mean pelvic position to be $11.3 \pm 5.7^{\circ}$ on both sides, ${ }^{18}$ again similar to that found for our control group.

During the depressive episode, our patients showed mild left scapular abduction, which decreased during remission. It is known that changes in the position of the scapula adversely affect the shoulder, predisposing to injury and chronic pain. ${ }^{5}$ In the study conducted by Miranda, ${ }^{18}$ the mean scapular position was $2.4 \pm 0.5^{\circ}$, comparable to that found for our control group. ${ }^{18}$ In our study, patients with depression showed mild left scapular abduction, which is likely related to the increased kyphosis, since the scapula is located in the same region. There were no significant differences between the MDD group and the control group in terms of the other postural variables.

We found that, during episodes, there are measurable changes in the posture of individuals with MDD. Such changes included significant increases in head flexion, thoracic kyphosis, a trend toward pelvic retroversion and an increase in scapular distance, all of which interfere with the proper functioning of the skeletal muscles. During remission, these aspects improved (Figure 1). Such alterations, in addition to having consequences such as pain, tension and shortness of breath, are often part of the spectrum of symptoms observed in MDD, characterizing a "depressive posture."

\section{Body image}

During depressive episodes, the patients in the MDD group were mildly dissatisfied with their body image, and this was primarily attributable to sadness and discouragement. During remission, there was no apparent dissatisfaction with body image, probably due to a lessening of the depressive symptoms. Control subjects did not express any dissatisfaction with their body image. Therefore, in this aspect, the controls were no different than the patients during remission. Several studies have associated poor body image with eating disorders and depressive symptoms..$^{20,21}$ One such study evaluated patients with class III obesity, analyzing periodic episodes of compulsive eating, anxiety, depression and body image distortion. ${ }^{21}$ In that study, all of the participants were found to have depressive symptoms, and 76\% expressed concerns regarding body image. In our study, care was taken to study only patients with a specific diagnosis of MDD, rather than all patients with depressive symptoms, which increases the relevance of our findings.

In a study involving a sample of the young adult female population of Sweden, the mean BSQ score was 74.50 \pm 29.50 , similar to that found for our controls. ${ }^{22}$ A study conducted in Brazil showed that, in a group of 582 female and male university employees, most $(90.2 \%)$ expressed no dissatisfaction with their body image, the mean BSQ score being $65.06 \pm 31.66,{ }^{23}$ which is also in agreement with our findings. In another study evaluating
193 young adult female students of nutrition, 59.9\% expressed no dissatisfaction with their body image, and there was a significant association between BSQ and BMI $(\mathrm{p}=0.026) .{ }^{24}$ In a review of the literature on body image, ${ }^{25}$ it was concluded that current investigations are increasingly focusing on physical appearance, particularly body shape and weight. For men, body image is less clear, because there have been fewer studies. For women, dissatisfaction with body size and weight is well documented, showing that the body image concept must be extended. Most studies on adults evaluated student populations within a narrow age range of 18-25 years, and those populations were typically homogeneous in terms of race, socioeconomic status and level of education. ${ }^{25}$

\section{Conclusion}

Patients with MDD showed changes in body posture during their episodic depressive exacerbation and expressed dissatisfaction with their body image. These alterations were not finding during the remission phase. These findings highlight the role of body posture and body image in the expression and communication of mood disorders and support the hypothesis that depression is related to impairments in both emotional and physical health domains.

\section{Acknowledgements}

This study was supported in part by the Coordenação de Aperfeiçoamento de Pessoal de Nível Superior (CAPES, Coordination of the Advancement of Higher Education). 


\section{Disclosures}

\begin{tabular}{|c|c|c|c|c|c|c|c|}
\hline $\begin{array}{l}\text { Writing group } \\
\text { member }\end{array}$ & Employment & $\begin{array}{l}\text { Research } \\
\text { grant }^{1}\end{array}$ & $\begin{array}{c}\text { Other research grant } \\
\text { or medical continuous } \\
\text { education }\end{array}$ & $\begin{array}{l}\text { Speaker's } \\
\text { honoraria }\end{array}$ & $\begin{array}{c}\text { Ownership } \\
\text { interest }\end{array}$ & $\begin{array}{l}\text { Consultant/ } \\
\text { Advisory } \\
\text { board }\end{array}$ & Other $^{3}$ \\
\hline $\begin{array}{l}\text { Janette Zamudio } \\
\text { Canales }\end{array}$ & $\begin{array}{l}\text { Private } \\
\text { practice }\end{array}$ & CAPES $^{\star * *}$ & - & - & - & - & - \\
\hline $\begin{array}{l}\text { Táki } \\
\text { Athanássios } \\
\text { Cordás }\end{array}$ & $\begin{array}{l}\text { Private } \\
\text { practice } \\
\text { USP }\end{array}$ & - & - & - & - & - & - \\
\hline $\begin{array}{l}\text { Juliana Teixeira } \\
\text { Fiquer }\end{array}$ & $\begin{array}{l}\text { Private } \\
\text { practice }\end{array}$ & - & - & - & - & - & - \\
\hline $\begin{array}{l}\text { André Furtado } \\
\text { Cavalcante }\end{array}$ & $\begin{array}{l}\text { Private } \\
\text { practice } \\
\text { USP }\end{array}$ & - & - & - & - & - & - \\
\hline $\begin{array}{l}\text { Ricardo Alberto } \\
\text { Moreno }\end{array}$ & $\begin{array}{l}\text { Private } \\
\text { practice } \\
\text { USP }\end{array}$ & $\begin{array}{c}\text { FAPESP } \\
\text { Bristol Mayers } \\
\text { Squibb } \\
\text { Servier } \\
\text { AstraZeneca } \\
\text { As**}\end{array}$ & $\begin{array}{c}\text { Medley } \\
\text { Cristália } \\
\text { Pfizer } \\
\text { Solvay Farma } \\
\text { Solução Editora \& } \\
\text { Publicidade }\end{array}$ & - & - & $\begin{array}{c}\text { CEIP } \\
\text { ABTB } \\
\text { ABP } \\
\text { ABNC }\end{array}$ & $\begin{array}{l}\text { Segmento } \\
\text { Farma } \\
\text { Editoras } \\
\text { Artmed } \\
\text { Editora SA }\end{array}$ \\
\hline
\end{tabular}

*Modest

**Significant

***Significant. Amounts given to the author's institution or to a colleague for research in which the author has participation, not directly to the author. Note: USP = Universidade de São Paulo; CAPES = Coordenação de Aperfeiçoamento de Pessoal de Nivel Superior; CEIP = Centro de Estudos do Instituto de Psiquiatria do Hospital das Clínicas da Faculdade de Medicina da Universidade de São Paulo; ABTB = Associação Brasileira de Transtorno Bipolar; $A B P=$ Associação Brasileira de Psiquiatria; $A B N C=$ Associação Brasileira de Neurociência Clínica.

For more information, see Instructions for Authors.

References

1. Kaplan IH, Sadock BJ. Compêndio de psiquiatria dinâmica. Porto Alegre: Artes Médicas; 1994

2. Moreno DH, Dias RS, Moreno RA. Psiquiatria básica. Porto Alegre: Artmed; 2007.

3. Shumway-Cook A, Woollacott MH. Motor control: theory and practical applications. Maryland: Lippincott Williams and Wilkins; 2001.

4. Brito Jr. CA. Alteraçôes posturais. In: Lianza S. Medicina de reabilitação. Rio de Janeiro: Guanabara Koogan; 1995.

5. Kendall FP, McCreary EK. Músculos: provas e funçōes. 3a ed. São Paulo: Manole; 1996.

6. Wright EF, Domenech MA, Fischer JR Jr. Usefulness of posture training for patients with temporomandibular disorders. J Am Dent Assoc. 2000;131(2):202-10.

7. Smith LK, Weiss EL, Lehmkuhl LD. Cinesiologia clinica de brunnstron. 5a ed. São Paulo: Manole; 1997.

8. Rasch PJ, Burke RK. Cinesiologia e anatomia aplicada. 5a ed. Rio de Janeiro: Guanabara Koogan; 1977.

9. Iunes DH, Castro FA, Salgado HS, Moura IC, Oliveira AS, Bevilaqua-Grossi D. Confiabilidade intra e interexaminadores e repetibilidade da avaliação postural pela fotogrametria. Rev Bras Fisioter. 2005;9(3):327-34.

10. Watson AW. Procedure for the production of high quality photographs suitable for the recording and evaluation of posture. Rev Fisioter Univ São Paulo. 1998;5(1):20-6.

11. Watson AW, Mac Donncha C. A reliable technique for the assessment of posture: assessment criteria for aspects of posture. J Sports Med Phys Fitness. 2000;40(3):260-70.

12. Schilder P. A imagem do corpo: as energias construtivas da psique. 2 ed. São Paulo: Martins Fontes; 1994.

13. Slade PD. What is body image? Behav Res Ther. 1994;32(5):497-502.

14. Cordás TA, Neves JEP. Escalas de avaliação de transtornos alimentares. Rev Psiquiatr Clín (São Paulo). 1999;26(1):41-7.

15. Gentil V, Zilberman ML, Lobo D, Henna E, Moreno RA, Gorenstein C. Clomipramine - induced mood and perceived performance changes in selected healthy individuals. J Clin Psychopharmacol. 2007;27(3):314-5.

16. Penha PJ, João SM, Casarotto RA, Amino CJ, Penteado DC. Postural assessment of girls between 7 and 10 years of age. Clinics (São Paulo). 2005;60(1):9-16.
17. Magee JD. Avaliação musculoesquelética. São Paulo: Manole; 2005.

18. Miranda R. Avaliação postural em mulheres com dor pélvica crônica [dissertação]. São Paulo: Faculdade de Medicina, Universidade Federal de São Paulo; 2007.

19. Ferreira EAG. Postura e controle postural: desenvolvimento e aplicação de método quantitativo de avaliação postural [tese]. São Paulo: Faculdade de Medicina, Universidade de São Paulo; 2005.

20. Cooper MJ. Beliefs and their relationship to eating attitudes and depressive symptoms in men. Eat Behav. 2006;7(4):423-6.

21. Matos MI, Aranha LS, Faria AN, Ferreira SR, Josué B, Zanella MT. Binge eating disorder, anxiety, depression and body image in grade III obesity patients. Rev Bras Psiquiatr. 2002;24(4):165-9.

22. Gadheri A, Scott B. The reliability and validity of the Swedish version of the Body Shape Questionnaire. Scand J Psychol. 2004;45(4):319-24.

23. Faria GP. Body Shape Questionnaire e Self Report Questionnaire - Em 20 funcionários de uma Universidade no Sul de Minas Gerais [dissertação]. Minas Gerais: Faculdade de Medicina, Universidade do Vale do Sapucaí; 2006.

24. Bosi ML, Luiz RR, Morgado CM, Costa ML, Carvalho RJ. Autopercepção da imagem corporal entre estudantes de nutrição: um estudo no município do Rio de Janeiro. J Bras Psiquiatr. 2006;55(2):108-13.

25. Tiggemann M. Body image across the adult life span: stability and change. Body Image. 2004;1(1):29-41. 